\title{
Predictors of Entrepreneurial Intention of Nursing Students Based on Theory of Planned Behavior
}

This article was published in the following Dove Press journal:

Journal of Multidisciplinary Healthcare

\author{
Ji Young Lim' \\ Geun Myun Kim² \\ Eun Joo Kim (1D ${ }^{2}$
}

'Department of Nursing, Inha University, Incheon City, 22212, South Korea; ${ }^{2}$ Department of Nursing, GangneungWonju National University, Wonju City, Gangwondo, 26403, South Korea
Correspondence: Eun Joo Kim Department of Nursing, GangneungWonju National University, I 50

Namwonro Heungup-Myun, Wonju City, Gangwondo, 26403, South Korea

$\mathrm{Tel}+82-33-760-8650$

$\mathrm{Fax}+82-33-760-8640$

Email kimeju@gwnu.ac.kr
Purpose: The theory of planned behavior has previously been applied as a theoretical framework for improving entrepreneurial intention in nurses. Our study aimed to draw major variables from these studies and establish a structural equation model that defines predictors explaining nursing entrepreneurial intention.

Participants and Methods: Participants included 252 nursing students from four nursing colleges in urban cities of South Korea. The structural equation model was constructed using six variables. Entrepreneurial-personal attitude, entrepreneurial-subjective norm, and entrepreneurial-perceived behavioral control from the theory of planned behavior model were used as exogenous variables, and entrepreneurial education demand, entrepreneurial selfefficacy, and entrepreneurial intention were used as endogenous variables. The data were analyzed using the SAS and LISREL programs.

Results: Entrepreneurial perceived behavioral control, entrepreneurial education demand, and entrepreneurial self-efficacy directly affected entrepreneurial intention, whereas entrepreneurial personal attitude and entrepreneurial subjective norm had indirect effects. The explanatory power of the modified model for entrepreneurial intention was $76.0 \%$. These results suggested that expanding entrepreneurial education opportunities and developing interventions for enhancing entrepreneurial self-efficacy are necessary to improve entrepreneurial intention in nursing students.

Conclusion: The results of this study will be used as basic data for developing curriculums and intervention programs to increase entrepreneurial intention in nursing students. To do this, we suggest that new pedagogies involving entrepreneurial project-based classes, business idea contests, and research and technology are useful tools to facilitate the next step of practical entrepreneurial preparation. Furthermore, an entrepreneurship-oriented culture needs to be fostered and include entrepreneur mentoring, team building, cooperative communication techniques, funding support, and a college-level support system.

Keywords: entrepreneurship, attitude, self-efficacy, education, demand

\section{Introduction}

Along with changes in the medical environment, the opportunities for nursing entrepreneurship are rapidly growing; bio healthcare is booming simultaneously with the fourth industrial revolution. ${ }^{1}$ Kim and Lim $^{2}$ emphasized facilitating nursing entrepreneurship by searching for entrepreneurial opportunities based on accumulated knowledge and experience across the new medical industry. Therefore, the environment for diverse and vital nursing entrepreneurship needs to be established to allow nursing students to realize their interests, and design and prepare a career path in nursing entrepreneurship during college or after graduation. South Korea is developing various policies to support entrepreneurship to increase 
the rate of youth entrepreneurship and has recently been encouraging college students who need to choose their career path after graduation. ${ }^{3}$ As the accumulation of entrepreneurial knowledge and experience during college can lead to the actual foundation of start-ups even during school years, various programs and policies supporting entrepreneurship among college students are emerging. $\mathrm{Du}^{3}$ emphasized that various on-site experiences offering entrepreneurial familiarity and confidence need to be provided in addition to related lectures and business idea competitions.

However, the proportion of nursing entrepreneurial education compared to other coursework is quite low in college curriculums. ${ }^{4}$ Kim et $\mathrm{al}^{4}$ have reported that limited studies on entrepreneurial education in the nursing field and in general have contributed to low awareness of nursing entrepreneurship in South Korea. Lee ${ }^{1}$ suggested that a choice between a career path in nursing offering employment or self-employment is considered a personal decision, and career advice provided in college has focused on getting students employed. Hence, various forms of support are needed from colleges, such as creating an educational environment and system to equip nursing students with the abilities required to become nursing entrepreneurs or nursing executives.

As college-level entrepreneurial education has an effect on improving entrepreneurial intention, ${ }^{4,5}$ offering entrepreneurship-related experiences to nursing students through training and lectures can improve their entrepreneurial intention and lay the foundation for vital nursing entrepreneurship. Yoo $^{6}$ proposed that the first step in entrepreneurship is not entrepreneurial preparation but growing an interest in entrepreneurship overall. Entrepreneurial interest and technical skills are needed at this step to encourage students' recognition of entrepreneurial values, and ultimately, its actual implementation.

Despite such previous research, a dominant theoretical model that explains entrepreneurial intention among nursing still does not exist. ${ }^{2}$ The factors associated with entrepreneurship vary largely depending on the specific industry and are affected by individual, environmental, and social factors. Hence, explaining entrepreneurial intention in various fields with a single model is nearly impossible. Several studies on entrepreneurial intention explained the concept mainly based on the theory of planned behavior (TPB) model $^{7,8}$ or classified the factors influencing entrepreneurial intention as personal, environmental, and social factors through the literature review without a theoretical model. ${ }^{3}$ Lee $^{1}$ presented career orientation, entrepreneurial spirit, entrepreneurial self-efficacy, entrepreneurial education, and entrepreneurial support as influencing factors on entrepreneurial intention among nursing students.

Entrepreneurial intention in the nursing field has independent characteristics distinct from other industrial fields. It is difficult to determine applicable factors explaining nursing entrepreneurial intention based only on previous studies. Lee ${ }^{1}$ established a predictive model for entrepreneurial intention among nursing students with a $44.5 \%$ explanatory power. Such a low explanatory power was caused by applying predictive factors of entrepreneurial intention from college students with a different major to their model, since few studies analyzed it among nursing students. Lee ${ }^{1}$ presented the need for establishing a model with higher explanatory power and proposed to build a model including psychological characteristics and environmental factors associated with nursing students' entrepreneurial intention.

Our study aimed to establish a theoretical model, which explains entrepreneurial intention among nursing students by developing a structural equation model that comprehensively demonstrates correlations among the influencing factors that predict nursing entrepreneurial intention. Our findings provide basic data for developing entrepreneurial education programs and interventions in nursing.

\section{Theoretical Model}

In this structural equation modeling study, a theoretical model based on Ajzen's ${ }^{9}$ TPB was established. Ajzen ${ }^{9}$ defined the TPB on the premise that human behavior requires a certain set of plans, while the behavior can be predicted based on the intention to select a particular behavior over others. The TPB states that an action as the selected target behavior is performed when the intention to accomplish the target behavior increases with a more favorable subjective norm, stronger perceived behavior control, and a more positive attitude towards the target behavior. Armitage and Conner ${ }^{10}$ analyzed the effect size through a meta-analysis of 185 studies involving the TPB and found that the three elements of the TPB could explain $39.7 \%$ of the behavioral intention. Liñán and Chen ${ }^{11}$ developed a model of entrepreneurial intention based on Ajzen's ${ }^{9}$ TPB and claimed that the subjective norm was the primary factor that influenced attitude and perceived behavior control. They highlighted the need for 
studies regarding the suitability of the model to be conducted across countries as the subjective norm is under the influence of the social and cultural values of a given country. Do Paco et $\mathrm{al}^{12}$ developed another model of entrepreneurial intention based on the TPB, whereby they found a positive effect of entrepreneurial attitude on perceived behavior control, so that an emphasis was placed on the importance of changing the attitude of an individual towards entrepreneurship prior to enriching them with the required knowledge and techniques.

Van Gelderen et al, ${ }^{13}$ likewise, suggested that the three elements of the TPB were the critical variables that affect the entrepreneurial intention alongside the subjective norm, as it was found in their study on 1225 undergraduate students that attitude was affected by financial security, and perceived behavior control was affected by entrepreneurial opportunity search. Autio et $\mathrm{al}^{14}$ also reported that attitude, subjective norm, and perceived behavior control all exerted a significant influence on entrepreneurial intention, in their study on 3445 undergraduate students regarding the empirical evaluation of the TPB. As can be seen, the TPB has been adopted by numerous scholars as a theoretical model with high utility for describing the entrepreneurial intention.

Entrepreneurial intention of college students is largely affected by the interactions between their psychological characteristics and environmental factors. Robinson et $\mathrm{al}^{15}$ investigated the entrepreneurial intention based on personal characteristics such as achievement, self-esteem, personal control, and innovation. Krueger and Brazeal ${ }^{16}$ added the element of self-efficacy to the TPB as a concept of perceived feasibility. Entrepreneurial selfefficacy is a psychological resource contributing to the psychological drive to realize one's entrepreneurship in the preparation process, and it has been reported that higher entrepreneurial self-efficacy leads to higher drive for entrepreneurship. ${ }^{17}$ Bird $^{18}$ viewed entrepreneurial intention as a combination of personal and environmental factors, and proposed market changes and government policies as the environmental factors. Luthje and Franke $^{19}$ conducted a study on undergraduate students majoring in engineering, and found a direct influence of perceived barriers and perceived support on entrepreneurial intention as two of the environmental factors. Hallam, Leffel and Womack $^{20}$ reported that entrepreneurial education such as a presentation of successful cases or lectures from an entrepreneur could raise the level of perceived feasibility to lead to a positive impact on entrepreneurial intention.

Based on the findings of previous studies, in this study's theoretical framework, entrepreneurial self-efficacy was selected as a psychological characteristic that affects entrepreneurial intention. Boyd and Vozikis ${ }^{21}$ considered selfefficacy as a crucial factor that increases entrepreneurial intention and influences the selection of entrepreneurial behaviors, which are led by intention. Demand for entrepreneurial education was selected as an environmental factor that affects entrepreneurial intention and was determined to be a significant factor influencing entrepreneurial intention in studies done by Yang and $\mathrm{Nam}^{22}$ and Lee. ${ }^{1}$

Our hypothetical model consisted of three exogenous variables and three endogenous variables based on the theoretical framework and literature review. The exogenous variables included entrepreneurial-personal attitude, entrepreneurialsubjective norm, and entrepreneurial-perceived behavioral control. The endogenous variables included entrepreneurial education demand, ${ }^{1}$ entrepreneurial self-efficacy, ${ }^{21}$ and entrepreneurial intention. Among exogenous variables, entrepreneurial personal attitude referred to a relatively consistent and systematic acquired tendency of responding either favorably or unfavorably to entrepreneurship. An entrepreneurial subjective norm referred to the degree of perceiving and accepting others' opinions on one's entrepreneurial behavior. Entrepreneurial perceived behavior control referred to the degree of individual perception about the difficulty or ease of implementing entrepreneurial behaviors. ${ }^{9}$ Among endogenous variables, entrepreneurial education demand referred to a need for education based on the knowledge, technology, and values required for entrepreneurship. ${ }^{1}$ Entrepreneurial selfefficacy referred to a belief in one's abilities to undertake entrepreneurship or a given task. ${ }^{1}$

Entrepreneurial intention referred to the subjective assessment of one's potential for executing entrepreneurship in the future. ${ }^{23}$ In the hypothetical model, entrepreneurial-personal attitude, entrepreneurial-subjective norm, and entrepreneurialperceived behavioral control were set to directly or indirectly affect entrepreneurial education demand, entrepreneurial selfefficacy, and entrepreneurial intention; entrepreneurial education demand and entrepreneurial self-efficacy were set to directly affect entrepreneurial intention (Figure 1).

\section{Purpose}

The purpose of this study was to establish a structural equation model that defines predictors explaining nursing entrepreneurial intention. 


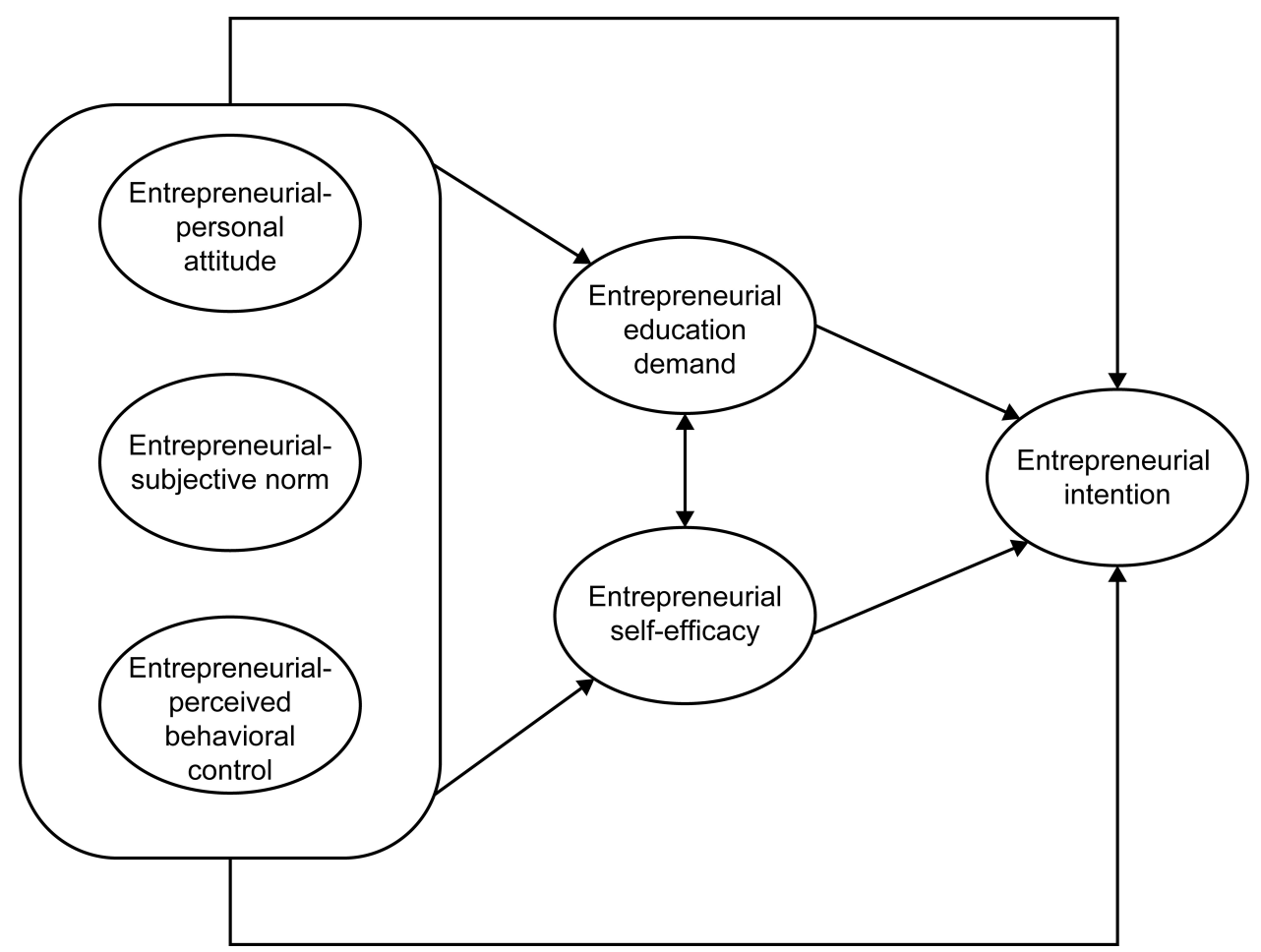

Figure I Theoretical model for this study.

\section{Definition of Entrepreneurial Intention}

Intention is a fundamental factor in describing human behavior, wherein it represents the intention to perform actions as an entrepreneur. ${ }^{24}$ In this study, entrepreneurial intentions refer to the psychological determination towards successful entrepreneurship, and higher levels of entrepreneurial intentions indicate a higher ability to overcome an obstacle or difficult situation once the business has been established. ${ }^{25}$

\section{Participants and Methods \\ Design}

This study developed a structural equation model to define the predictors influencing entrepreneurial intention among nursing students.

\section{Sample}

Participants were selected among nursing students attending four nursing colleges located in urban cities in South Korea utilizing self-reported surveys. Those who understood the purpose of this study and agreed to participate were included, and 252 questionnaires were used in the final analysis. The sample size was calculated following the standard requirement of at least 200 participants for structural equation model validation, ${ }^{26}$ and anticipating a $30 \%$ standard dropout rate.

\section{Measures}

\section{Entrepreneurial-Personal Attitude}

Entrepreneurial-personal attitude was measured using an instrument modified by $\mathrm{Lim}^{27}$ based on TPB. This instrument consists of five questions, which are rated on a fivepoint Likert scale. Higher scores indicate a higher level of entrepreneurial-personal attitude. Cronbach's alpha was 0.93 in Lim's ${ }^{27}$ study and 0.93 in our study.

\section{Entrepreneurial-Subjective Norm}

Entrepreneurial-subjective norm was measured using an instrument modified by $\mathrm{Lim}^{27}$ based on the TPB. This instrument comprises three questions, which are rated on a five-point Likert scale. Higher scores indicate a higher level of entrepreneurial-subjective norm. Cronbach's alpha was 0.86 in Lim's ${ }^{27}$ study and 0.91 in our study.

\section{Entrepreneurial-Perceived Behavioral Control}

Entrepreneurial-perceived behavioral control was measured using an instrument modified by $\mathrm{Lim}^{27}$ based on the TPB. This instrument comprises six questions, which are rated on a five-point Likert scale. Higher scores indicate a higher level of entrepreneurial perceived behavioral control. Cronbach's alpha was 0.93 in Lim's ${ }^{27}$ study and 0.96 in our study. 


\section{Entrepreneurial Education Demand}

Entrepreneurial education demand was measured using an instrument developed by Hwang. ${ }^{28}$ This instrument consists of four questions, which are rated on a five-point Likert scale. Higher scores indicate a higher level of entrepreneurial education demand. Cronbach's alpha was 0.84 in Lim et $\mathrm{al}^{29}$ study and 0.90 in our study.

\section{Entrepreneurial Self-Efficacy}

Entrepreneurial self-efficacy was measured using an instrument developed by Yoon, ${ }^{30}$ and modified by Huh. ${ }^{31}$ This instrument consists of 15 questions, which are rated on a five-point Likert scale. Higher scores indicate a higher level of entrepreneurial self-efficacy. Cronbach's alpha was 0.91 in Huh's ${ }^{31}$ study and 0.94 in our study.

\section{Entrepreneurial Intention}

Entrepreneurial intention was measured using an instrument developed by Lim. ${ }^{27}$ This instrument consists of six questions, which are rated on a five-point Likert scale. Higher scores indicate a higher level of entrepreneurial intention. Cronbach's alpha was 0.96 in Lim's ${ }^{27}$ study and 0.92 in our study.

\section{Data Collection}

Data were collected from participants between December 12, 2018 and January 28, 2019. Before the survey, directors from each college approved the survey. The self-reported questionnaires were sent and retrieved by mail.

\section{Ethical Considerations}

The study was first approved by the Institution Review Board of Gangneung-Wonju National University (GWNUIRB-201812). After obtaining permission from the director of the Department of Nursing, participants were recruited via a posting on the bulletin board. The study purpose and procedures were explained to participants. Participants' privacy and anonymity were assured, and their right to withdraw at any time was disclosed. Written informed consent was obtained from everyone who participated. This study was conducted in accordance with the Declaration of Helsinki.

\section{Analysis}

General characteristics of the study participants and correlation of study variables were analyzed using the SAS program (version 9.1). Validation of the hypothetical model and analysis of each path were conducted using the LISREL program (version 8.5 for Windows). To assess whether the hypothetical model fit the actual data, validation of fitness was conducted using overall fit indices. The overall fit indices included $\chi^{2}$ (Chi-square), root mean square residual (RMR), goodness of fit Index (GFI), adjusted goodness of fit index (AGFI), non-normed fit index (NNFI), normed fit index (NFI), and root mean square error of approximation (RMSEA). To estimate the parameters, weighted least squares were used, which were suitable as the skewness and kurtosis were high and less affected by distribution.

\section{Results General Characteristics}

Participants' mean age was 22.91 years $(\mathrm{SD}=2.83)$. Participants consisted of 28 male students (11.1\%) and 224 female students (88.9\%). There were 17 freshmen (6.8\%), 84 sophomores (33.5\%), 113 juniors (45\%), and 37 seniors (14.7\%). Two hundred and eighteen students (87.2\%) had part-time job experience. The mean monthly allowance was 356,200 won $(\fallingdotseq \$ 356)(\mathrm{SD}=19.40)$. One hundred and seventy-nine students $(73.1 \%)$ had no experience with entrepreneurship-related education whereas 66 students $(26.9 \%)$ had some experience.

\section{Correlation Among Variables}

Correlation analysis on major variables showed statistically significant positive correlations. Correlation coefficients ranged from 0.51 to 0.77 . The variables with the strongest correlation were entrepreneurial intention and entrepreneurial self-efficacy (Table 1).

\section{Model Evaluation}

To assess whether the hypothetical model fit the actual data, validation of fitness was conducted using overall fit indices. To increase the fitness and compose a suitable model, the hypothetical model was modified by adding a statistically significant path (entrepreneurial self-efficacy -> entrepreneurial education demand) and correlation (entrepreneurialpersonal attitude-entrepreneurial-perceived behavior control, entrepreneurial-personal attitude-entrepreneurial-subjective norm), and deleting the statistically insignificant path (entrepreneurial-personal attitude-entrepreneurial intention, entrepreneurial-personal attitude-entrepreneurial self-efficacy). The results showed that the overall fit indices of the modified model were acceptable with $\chi^{2} / \mathrm{df}=1.94(p=0.38)$, $\mathrm{RMR}=0.069, \mathrm{GFI}=1.00, \mathrm{AGFI}=0.97, \mathrm{NNFI}=1.00, \mathrm{NFI}=$ 
Table I Correlations Among the Study Variables ( $N=252)$

\begin{tabular}{|l|c|c|c|c|c|c|}
\hline Variables & $\begin{array}{c}\text { Entrepreneurial- } \\
\text { Personal } \\
\text { Attitude }\end{array}$ & $\begin{array}{c}\text { Entrepreneurial- } \\
\text { Subjective Norm }\end{array}$ & $\begin{array}{c}\text { Entrepreneurial- } \\
\text { Perceived Behavioral } \\
\text { Control }\end{array}$ & $\begin{array}{c}\text { Entrepreneurial } \\
\text { Education } \\
\text { Demand }\end{array}$ & $\begin{array}{c}\text { Entrepreneurial } \\
\text { Self-Efficacy }\end{array}$ & $\begin{array}{c}\text { Entrepreneurial } \\
\text { Intention }\end{array}$ \\
\hline $\begin{array}{l}\text { Entrepreneurial- } \\
\text { personal attitude }\end{array}$ & 1.00 & 1.00 & & & & \\
\hline $\begin{array}{l}\text { Entrepreneurial- } \\
\text { subjective norm }\end{array}$ & $0.65^{*}$ & $0.57^{*}$ & 1.00 & & \\
\hline $\begin{array}{l}\text { Entrepreneurial- } \\
\text { perceived behavioral } \\
\text { control }\end{array}$ & $0.52^{*}$ & $0.56^{*}$ & $0.51^{*}$ & 1.00 & \\
\hline $\begin{array}{l}\text { Entrepreneurial } \\
\text { education demand }\end{array}$ & $0.65^{*}$ & $0.68^{*}$ & $0.76^{*}$ & $0.61^{*}$ & 1.00 & 1.00 \\
\hline $\begin{array}{l}\text { Entrepreneurial self- } \\
\text { efficacy }\end{array}$ & $0.62^{*}$ & $0.63^{*}$ & $0.72^{*}$ & $0.73^{*}$ & & $0.77^{*}$ \\
\hline $\begin{array}{l}\text { Entrepreneurial } \\
\text { intention }\end{array}$ & $0.71^{*}$ & & & & 1 \\
\hline
\end{tabular}

Note: ${ }^{*} \mathrm{p}<0.001$

1.00 , and RMSEA $=0.00$. This suggested that the modified model properly explained the actual data (Table 2).

\section{Direct, Indirect, and Total Effects on Entrepreneurial Intention}

The direct, indirect, and total effects of the variables from the final modified model are shown in Table 3. Entrepreneurialperceived behavioral control $(\beta=0.24, \mathrm{t}=5.87)$, entrepreneurial education demand $(\beta=0.35, \mathrm{t}=7.15)$, and entrepreneurial self-efficacy $(\beta=0.34, \mathrm{t}=4.26)$ showed statistically significant direct effects, indicating that higher entrepreneurship-perceived behavioral control, higher entrepreneurial education demand, and higher entrepreneurial self-efficacy led to higher entrepreneurial intention. Entrepreneurialpersonal attitude had statistically significant indirect effects on entrepreneurial intention $(\beta=0.25, \mathrm{t}=6.29)$. Entrepreneurial-subjective norm $(\beta=0.10, \mathrm{t}=4.78)$, entrepreneurial-perceived behavioral control $(\beta=0.17, \mathrm{t}=4.53)$, entrepreneurial education demand $(\beta=0.06, \mathrm{t}=2.89)$, and entrepreneurial self-efficacy $(\beta=0.06, \mathrm{t}=3.76)$ also showed statistically significant indirect effects on entrepreneurial intention. The total effects of entrepreneurial-personal attitude, entrepreneurial-subjective norm, entrepreneurialperceived behavioral control, and entrepreneurial education demand on entrepreneurial intention were all statistically significant. The predictive variables explained $76 \%$ of entrepreneurial intention.
The variables that had statistically significant direct effects on entrepreneurial self-efficacy were the entrepreneurial-subjective norm $(\beta=0.26, t=6.03)$, entrepreneurial-perceived behavioral control $(\beta=0.41, \mathrm{t}=11.27)$, and entrepreneurial education demand $(\beta=0.14, \mathrm{t}=4.68)$. Entrepreneurial-personal attitude $(\beta=0.09, \mathrm{t}=4.78)$, entrepreneurial-subjective norm $(\beta=0.01, \mathrm{t}=2.29)$, and entrepreneurial-perceived behavioral control $(\beta=0.01, \mathrm{t}=$ 2.38) had statistically significant indirect effects. The total effects of entrepreneurial-personal attitude, entrepreneurial-subjective norm, entrepreneurial-perceived behavioral control, and entrepreneurial education demand on entrepreneurial self-efficacy were all statistically significant. These variables explained $70 \%$ of entrepreneurial selfefficacy.

The variables that had statistically significant direct effects on entrepreneurial education demand were entrepreneurialpersonal attitude $(\beta=0.61, t=10.94)$ and entrepreneurial selfefficacy $(\beta=0.14, t=4.68)$. Entrepreneurial-personal attitude $(\beta=0.02, t=2.42)$, entrepreneurial-subjective norm $(\beta=0.04$, $t=3.97)$, and entrepreneurial-perceived behavioral control $(\beta$ $=0.06, \mathrm{t}=4.65)$ had statistically significant indirect effects. The total effects of entrepreneurial-personal attitude, entrepreneurial-subjective norm, entrepreneurial-perceived behavioral control, and entrepreneurial self-efficacy on entrepreneurial education demand were all statistically significant. These variables explained $47 \%$ of the entrepreneurial education demand (Figure 2 and Table 3). 
Table 2 Model Fitness $(\mathrm{N}=252)$

\begin{tabular}{|l|c|c|c|c|c|c|c|}
\hline Fitness & $\chi^{2} / \mathbf{d f}(\boldsymbol{p})$ & RMR & GFI & AGFI & NFI & NNFI & RMSEA \\
\hline $\begin{array}{l}\text { Hypothetical } \\
\text { model }\end{array}$ & $\begin{array}{c}20.31 \\
(<.0001)\end{array}$ & 0.091 & 0.97 & 0.68 & 1.00 & 0.97 & 0.20 \\
\hline Modified model & $1.94(0.38)$ & 0.069 & 1.00 & 0.97 & 1.00 & 1.00 & 0.00 \\
\hline
\end{tabular}

Abbreviations: RMR, root mean square residual; GFI, goodness of fit index; AGFI, adjusted goodness-of-fit index; NFI, normed fit index; NNFI, non-normed fit index; RMSEA, root mean square error of approximation.

Table 3 Effects and Squared Multiple Correlations (SMCs) in the Modified Model $(\mathrm{N}=252)$

\begin{tabular}{|c|c|c|c|c|c|}
\hline Endogenous Variables & Predictor & $\begin{array}{l}\text { Direct } \\
\text { Effect (t) }\end{array}$ & $\begin{array}{l}\text { Indirect } \\
\text { Effect (t) }\end{array}$ & $\begin{array}{c}\text { Total } \\
\text { Effect }(t)\end{array}$ & SMC \\
\hline \multirow{4}{*}{$\begin{array}{l}\text { Entrepreneurial- education } \\
\text { demand }\end{array}$} & Entrepreneurial-personal attitude & $0.6 \mathrm{I}(10.94)^{* * *}$ & $0.02(2.42)^{*}$ & $0.63(11.28)^{* * *}$ & 0.47 \\
\hline & Entrepreneurial-subjective norm & & $0.04(3.97)^{* * *}$ & $0.04(3.97)^{* * *}$ & \\
\hline & $\begin{array}{l}\text { Entrepreneurial-perceived behavioral } \\
\text { control }\end{array}$ & & $0.06(4.65)^{* * *}$ & $0.06(4.65)^{* * *}$ & \\
\hline & Entrepreneurial self-efficacy & $0.14(4.68)^{* * *}$ & $0.01(1.54)$ & $0.15(4.49)^{* * *}$ & \\
\hline \multirow[t]{4}{*}{ Entrepreneurial- self-efficacy } & Entrepreneurial-personal attitude & & $0.09(4.78)^{* * *}$ & $0.09(4.78) * * *$ & 0.70 \\
\hline & Entrepreneurial-subjective norm & $0.26(6.03)^{* * *}$ & $0.01(2.29)^{*}$ & $0.27(6.08)^{* * *}$ & \\
\hline & $\begin{array}{l}\text { Entrepreneurial-perceived behavioral } \\
\text { control }\end{array}$ & $0.4 \mathrm{I}(\mathrm{II} .27)^{* * *}$ & $0.01(2.38)^{*}$ & $0.42(I I .55)^{* * *}$ & \\
\hline & Entrepreneurial education demand & $0.14(4.68)^{* * *}$ & $0.01(1.54)$ & $0.15(4.49)^{* * *}$ & \\
\hline \multirow[t]{5}{*}{ Entrepreneurial- intention } & Entrepreneurial-personal attitude & & $0.25(6.29)^{* * *}$ & $0.25(6.29)^{* * *}$ & 0.76 \\
\hline & Entrepreneurial-subjective norm & $0.09(1.84)$ & $0.10(4.78)^{* * *}$ & $0.19(4.11)^{* * *}$ & \\
\hline & $\begin{array}{l}\text { Entrepreneurial-perceived behavioral } \\
\text { control }\end{array}$ & $0.24(5.87)^{* * *}$ & $0.17(4.53)^{* * *}$ & $0.4 \mathrm{I}(\mathrm{II} .47)^{* * * *}$ & \\
\hline & Entrepreneurial education demand & $0.35(7.15)^{* * *}$ & $0.06(2.89)^{* *}$ & $0.4 \mathrm{I}(8.76)^{* * *}$ & \\
\hline & Entrepreneurial self-efficacy & $0.34(4.26)^{* * *}$ & $0.06(3.76)^{* * *}$ & $0.40(4.86)^{* * *}$ & \\
\hline
\end{tabular}

Notes: $*|t|>1.96(p<0.05) ; *|t|>2.56(p<0.01) ; * * *|t|>2.98(p<0.001)$

\section{Discussion}

In our model, $76.0 \%$ of the entrepreneurial intention among nursing students was explained. This is a relatively high explanatory power compared to $39.5 \%$ from Ha and Jung's ${ }^{32}$ study on the influencing factors of entrepreneurial intention among college students, $44.5 \%$ from Lee's ${ }^{1}$ study, $63.0 \%$ from Kim and Lim's ${ }^{2}$ study, and $39.9 \%$ from Lim et al's ${ }^{29}$ study. The explanatory model of entrepreneurial intention among nursing students in our study was validated as a simple and clear model composed of five variables, which also has a high explanatory power. Hence, our findings provided a useful theoretical model to explain the entrepreneurial intention of nursing students in future studies.
All three elements of Ajzen's ${ }^{9}$ TPB had direct and indirect effects on entrepreneurial intention. Entrepreneurial-perceived behavioral control had both direct and indirect effects whereas the other two factors had indirect effects, indicating that TPB is a significant theoretical model for explaining entrepreneurial intention among nursing students. Entrepreneurial-perceived behavioral control had the strongest effects on entrepreneurial intention. Entrepreneurial-perceived behavioral control posits that individuals will control behavior. ${ }^{9}$ When people believe they are in control of their own behavior, they are likely to execute their individual will. As entrepreneurship is a lengthy process to achieving business goals, it weighs importantly given that entrepreneurial-perceived behavioral control had strong effects on entrepreneurial intention among nursing 


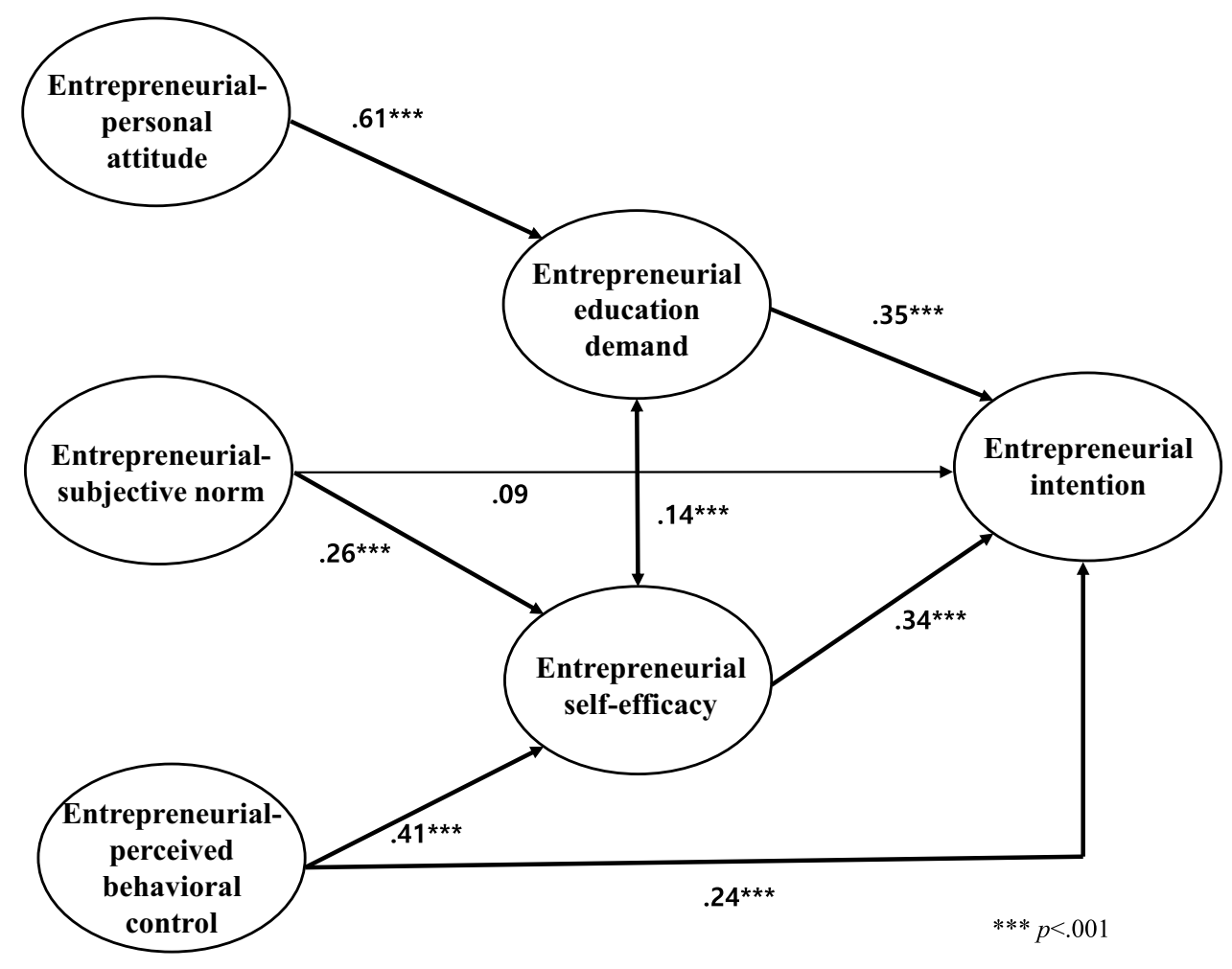

Figure 2 Path diagram for the modified model.

students. Entrepreneurial intention is the will to participate in entrepreneurial activities and is the best predictive variable for entrepreneurial behavior. $^{33}$ As entrepreneurial intention is a process recognized by people before they start their own business, ${ }^{11}$ it leads to a greater possibility of implementing entrepreneurial behavior and setting the goal of creating new value from an existing business. ${ }^{18}$

Both entrepreneurial education demand and entrepreneurial self-efficacy had direct effects on entrepreneurial intention. Higher entrepreneurial education demand led to higher entrepreneurial intention. This is consistent with Park et al's ${ }^{34}$ study that learning from experience was a critical success factor for venture entrepreneurs. Additionally, educational support is required because it can strengthen entrepreneurial skills and the desire to achieve success. ${ }^{35}$ Yoo $^{6}$ reported in an entrepreneurship-related study review that entrepreneurial education has been a continuous and active variable since the beginning of entrepreneurial research. Therefore, to vitalize entrepreneurial intention for nursing students, it needs to be introduced in the formal education curriculum. Lim et $\mathrm{al}^{29}$ reported that nursing entrepreneurial education could lower the uncertainty of entrepreneurship by offering necessary knowledge and techniques and increase the probability of successful entrepreneurship. Regarding this, the theory of management, marketing, and sharing of successful cases of entrepreneurship have been discussed as core contents for nursing entrepreneurial education curriculums. Ahn et $\mathrm{al}^{36}$ reported that the entrepreneurial education model utilizing team projects could strengthen creative skills and improve entrepreneurial self-efficacy and entrepreneurial intention in college students. Recently, project-based classes and entrepreneurial idea contests offering support like funding, manpower, and space have been proposed to promote actual entrepreneurship. These efforts will allow college students to have a positive outlook on entrepreneurship and actively engage in entrepreneurial activities.

Our study showed that entrepreneurial self-efficacy increased entrepreneurial intention among nursing students. This is consistent with previous studies, which showed entrepreneurial self-efficacy to be an antecedent variable that increases entrepreneurial intention. ${ }^{37,38} \mathrm{Hsu}$ et $\mathrm{al}^{39}$ defined entrepreneurial self-efficacy as a personal belief that one is capable of successfully performing the role of an entrepreneur and undertaking necessary tasks. Kim and $\mathrm{Lim}^{2}$ defined it as a conviction that one can successfully undertake activities necessary for achieving entrepreneurial goals. Thus, entrepreneurial self-efficacy is the ability to cope with stress caused by uncertain tasks during the 
process of business, which strengthens entrepreneurial intention by encouraging continuous efforts and trials to address challenging needs. ${ }^{40}$ Various opportunities are given to those with high entrepreneurial self-efficacy, but such opportunities can decrease for people with low entrepreneurial self-efficacy who see entrepreneurship as a risk and potential sacrifice. ${ }^{41}$ Higher entrepreneurial selfefficacy showed strong effects on entrepreneurial intention and reduced negative concern or pressure on business. ${ }^{42}$ Kim and $\mathrm{Lim}^{2}$ suggested that one-on-one mentoring from successful nursing entrepreneurs would increase nursing students' confidence levels and reinforce their skills to implement entrepreneurial activities.

Entrepreneurial-subjective norm and entrepreneurialpersonal attitude had indirect effects on entrepreneurial intention among nursing students. Entrepreneurialsubjective norm refers to the opinions of a perceived reference group. People's perceived beliefs about reference groups in relation to themselves influence whether they conduct a certain behavior. ${ }^{9}$ Fayolle et $\mathrm{al}^{43}$ showed that entrepreneurial-subjective norm had the strongest effect on entrepreneurial intention. Individuals' beliefs and perceptions about the positive and negative outcomes of behavior determine whether an individual favors or starts a new business. Entrepreneurial-personal attitude explains whether an individual will undertake such a risk. The ability to control one's behavior and entrepreneurial outcomes leads to entrepreneurial intention.

In summary, among the components of TPB, entrepreneurial-perceived behavioral control had the strongest effect on entrepreneurial intention among nursing students, suggesting it is the baseline factor that needs to be preferentially considered in developing support programs for nursing entrepreneurship in the future. In addition, to improve entrepreneurial education demand and entrepreneurial self-efficacy, the three components of TPB need to be strengthened as antecedent factors. Enhancing entrepreneurial-personal attitude, entrepreneurial-subjective norm, and entrepreneurial-perceived behavioral control will vitalize the entrepreneurial education demand and entrepreneurial self-efficacy. Moreover, the active interaction between these two factors will lead to strong entrepreneurial intention; energizing nursing students to choose a career path in nursing entrepreneurship.

\section{Conclusion}

Based on the analysis of factors influencing entrepreneurial intention among nursing students, entrepreneurial-perceived behavioral control from TPB showed direct and indirect effects on entrepreneurial intention among nursing students. Entrepreneurial education demand and entrepreneurial selfefficacy had significant direct effects on entrepreneurial intention through interaction. The explanatory power of the model was $76.0 \%$. Compared to previous studies, our study established a simple and clear model explaining the entrepreneurial intention of nursing students with high explanatory power where all variables had significant direct and indirect effects. The model established in this study can be used as a theoretical model for enhancing entrepreneurial intention among nursing students.

Based on these results, accessibility to entrepreneurial education should be reinforced in order to vitalize entrepreneurial intention among nursing students by creating a nursing entrepreneurship curriculum or promoting extracurricular activities that allow direct and indirect acquisition of entrepreneurial skills. To achieve this, new pedagogies involving entrepreneurial project-based classes, business idea contests, and research and technology development provide experiences and lead to the next step of practical entrepreneurial preparation. This approach moves beyond theoretical lessons focused on simply conveying knowledge. Furthermore, an entrepreneurshiporiented culture needs to be encouraged and include entrepreneur mentoring, team building, cooperative communication techniques, funding support, and a college-level support system.

\section{Author Contributions}

All authors made substantial contributions to conception and design, acquisition of data, or analysis and interpretation of data; took part in drafting the article or revising it critically for important intellectual content; agreed to submit to the current journal; gave final approval of the version to be published; and agree to be accountable for all aspects of the work.

\section{Funding}

The authors disclosed receipt of the following financial support for the research, authorship, and/or publication of this article: This work was supported by the Mid-Career Researcher Program of Basic Research through the National Research Foundation of Korea (NRF) and was funded by the Ministry of Science, and ICT (Information, Communication, Technology) [grant number NRF2020R1A2C1003670]. The funding source had no role in the study design; collection, analysis, and interpretation of data; writing of the report; or in the decision to submit the article for publication. 


\section{Disclosure}

The authors report no conflicts of interest in this work.

\section{References}

1. Lee OJ. A Predictive Model of the Entrepreneurial Intention of Nursing Students [doctoral dissertation]. Jeonbuk: Jeonbuk University; 2016.

2. Kim YJ, Lim JY. Factors influencing entrepreneurial intention of nursing students based on theory of planned behavior. $J$ Korean Acad Nurs Adm. 2019;25(3):175-185. doi:10.11111/jkana.2019.25.3.175

3. Du W. Comparative Study on the Influence Factors of Entrepreneurial Intention in College Students: Focusing on College Students Studying in China and Korea [master's thesis]. Chunchun: Kangwon National University; 2014.

4. Kim SW, Kang CW, Lee WS. The impact of leading universities for start-up business program on the entrepreneurial self-efficacy: focusing on the mediating effect of entrepreneurship and start-up capability. J Korean Data Anal Soc. 2016;18(5):2627-2636.

5. Yook CH, Jeon IO. Effect of entrepreneur's characteristics on the intention of entrepreneurship: focusing on the moderating effect of entrepreneurship mentoring in Korean. $J$ Korea Contents Assoc. 2014;14(10):661-676. doi:10.5392/JKCA.2014.14.10.661

6. Yoo JH. Meta-analysis about the study related with foundation: as the center from 1998 to 2013 treatises. Asia Pac J Bus Venturing Entrep. 2014;9(1):51-67. doi:10.16972/apjbve.9.1.201402.51

7. Kim SW, Kang MH. Entrepreneurial job search education's effects on the antecedents of university students' entrepreneurial job search intention. J Eng Educ Res. 2016;19(4):47-59. doi:10.18108/ jeer.2016.19.4.47

8. Lee SY. The effects of planned behavior of college students participating in education for starting an agricultural business on entrepreneurship and entrepreneurial intention. Asia Pac J Bus Venturing Entrep. 2018;13(1):145-155. doi:10.16972/apjbve.13.1.201802.145

9. Ajzen I. The theory of planned behavior. Organ Behav Hum Decis Process. 1991;50(2):179-211. doi:10.1016/0749-5978(91)90020-T

10. Armitage CJ, Conner M. Efficacy of the theory of planned behaviour: a meta analytic review. Br J Soc Psychol. 2001;40(4):471-499. doi:10.1348/014466601164939

11. Liñán F, Chen YW. Development and cross-cultural application of a specific instrument to measure entrepreneurial intentions. Entrep Theor Pract. 2009;33(3):593-617. doi:10.1111/j.1540-6520.2009.00318.x

12. Do paço AMF, Ferreira JM, Raposo M, Rodrigues RG, Dinis A. Behaviours and entrepreneurial intention: empirical findings about secondary students. J Int Entrep. 2011;9(1):20-38. doi:10.1007/ s10843-010-0071-9

13. Van Gelderen M, Brand M, van Praag M, Bodewes W, Poutsma E, Van Gils A. Explaining entrepreneurial intentions by means of the theory of planned behaviour. Career Dev Int. 2008;13(6):538-559. doi:10.1108/13620430810901688

14. Autio EH, Keeley R, Klofsten M, Parker GGC, Hay M. Entrepreneurial intent among students in Scandinavia and in the USA. Enterprise Innovat Manag Stud. 2001;2(2):145-160. doi:10.1080/14632440110094632

15. Robinson PB, Stimpson DV, Huefner JC, Hunt HK. An attitude approach to the prediction of entrepreneurship. Entrep Theory Pract. 1991;15(4):13-32. doi:10.1177/104225879101500405

16. Krueger NF, Brazeal DV. Entrepreneurial potential and potential entrepreneurs. Entrep Theory Pract. 1994;18(3):91-104. doi:10.1177/104225879401800307

17. Jahani S, Babazadeh M, Haghighi S, Cheraghian B. The effect of entrepreneurship education on self-efficacy beliefs and entrepreneurial intention of nurses. J Clin Diagn Res. 2018;12(6):18-21. doi: $10.7860 /$ jcdr/2018/31525.11654
18. Bird B. Implementing entrepreneurial ideas: the case for intentions. Acad Manag Rev. 1988;13(3):442-453. doi:10.5465/ amr.1988.4306970

19. Lüthje C, Franke N. The 'making' of an entrepreneur: testing a model of entrepreneurial intent among engineering students at MIT. $R$ D Manag. 2003;33(2):135-147. doi:10.1111/1467-9310.00288

20. Hallam CR, Leffel A, Womack D Influencing entrepreneurial intent for new technology intrapreneurs and entrepreneurs in a university environment. In: PICMET' 08-2008 Portland International Conference on Management of Engineering \& Technology; July, 2008; Cape Town: IEEE; 754-763.

21. Boyd NG, Vozikis GS. The influence of self-efficacy on the development of entrepreneurial intentions and actions. Entrep Theor Pract. 1994;18(4):63-77. doi:10.1177/104225879401800404

22. Yang JJ, Nam JH. Entrepreneurship motivation and entrepreneurship education satisfaction the entrepreneurship preparation behavior, the effect on self-efficacy and food service entrepreneurship. Korean J Tourism Res. 2015;30(6):47-66.

23. Lee JW. Individual characteristics and entrepreneurial intentions. Korean Small Bus Rev. 2000;22(1):121-146. doi:10.17287/kbr.2018.22.4.121

24. Liñán F. Intention-based models of entrepreneurship education. Piccola Impresa Small Business. 2004;3:11-35.

25. Krueger NF, Reilly MD, Carsrud AL. Competing models of entrepreneurial intentions. $J$ Bus Ventur. 2000;15(5-6):411-432. doi:10.1016/S0883-9026(98)00033-0

26. Hoelter JW. The analysis of covariance structures: goodness-of-fit indices. Sociol Methods Res. 1983;11(3):325-344. doi:10.1177/ 0049124183011003003

27. Lim J The Study on the Crucial Factor Influencing the Entrepreneurial Intentions [dissertation]. Gyeongnam, South Korea: Jinju National University; 2010.

28. Hwang JS College Students' Entrepreneurial education demand and Their Entrepreneurial Intention [doctoral dissertation]. Chunan: Hoseo University; 2006.

29. Lim JY, Kim KM, Ko KJ. Influence of entrepreneurship, personality traits, and need for entrepreneurial education on entrepreneurial intention in nursing students. Korean Data Anal Soc. 2017;19 (6):3361-3377. doi:10.37727/jkdas.2017.19.6.3361

30. Yoon BS. Determining factors of entrepreneurial intention: individual characteristics and environmental factors. Korean Bus Rev. 2004;17 (2):89-110.

31. Huh MY The Effects of Chinese College Students' Role Model on Entrepreneurial Intention: focusing on the Mediating Effects of Entrepreneurial Self-Efficacy [master's thesis]. Seoul, South Korea: Soongsil University; 2014.

32. Ha GS, Jung YB. Recognition of business failure and success of entrepreneurial intention of university students. J Korea Acad Industr Coop Soc. 2011;12(8):3406-3414.

33. Ferreira JJ, Raposo ML, Gouveia Rodrigues R, Dinis A, Do Paço A. A model of entrepreneurial intention: an application of the psychological and behavioral approaches. J Small Bus Enterpr Dev. 2012;19 (3):424-440. doi:10.1108/14626001211250144

34. Park I, Joo JH, Jeong BG. The effects of self-leadership and self-efficacy on the entrepreneurship intention: mediated effect of entrepreneurship and moderated mediating effect of entrepreneurial participation. J Korea Assoc Hum Resour Dev. 2017;20(3):159-177. doi:10.24991/KJHRD.2017.09.20.3.159

35. Lee YH, Park SH. A study on the success factors of venture entrepreneurs and entrepreneurship education. Asia Pac J Bus Venturing Entrep. 2014;9(6):231-244. doi:10.16972/apjbve.9.6. 201412.231

36. Ahn TU, Lee IH, Park JH. A study on the effects of creativity competency education on self-efficacy and entrepreneurial intention: the moderating role of social support through parent cooperation. Asia Pac J Bus Venturing Entrep. 2017;12(6):25-39. doi:10.16972/ apjbve.12.6.201712.25 
37. Piperopoulos P, Dimov D. Burst bubbles or build steam? Entrepreneurship education, entrepreneurial self-efficacy, and entrepreneurial intentions. J Small Bus Manag. 2015;53(4):970-985. doi:10.1111/jsbm. 12116

38. Tsai KH, Chang HC, Peng CY. Extending the link between entrepreneurial self-efficacy and intention: a moderated mediation model. Int Entrep Manag. 2016;12(2):445-463. doi:10.1007/s11365-014-0351-2

39. Hsu DK, Wiklund J, Cotton RD. Success, failure, and entrepreneurial reentry: an experimental assessment of the veracity of self-efficacy and prospect theory. Entrep Theor Pract. 2017;41(1):19-47. doi:10.1111/etap.12166

40. Jeong DY, Chae YH. The effect of employability on the entrepreneurial intention: focus on double mediation role of self-leadership and self-efficacy. Korean J Bus Admin. 2016;29(3):467-488.
41. McGee JE, Peterson M, Mueller SL, Sequeira JM. Entrepreneurial self-efficacy: refining the measure. Entrep Theor Pract. 2009;33 (4):965-988. doi:10.1111/j.1540-6520.2009.00304.x

42. Hyun SH, Seo MK, Kwon IS. The moderating effects of core-self evaluation on the relationship between entrepreneurial self-efficacy and entrepreneurial intention, job-seeking stress. Asia Pac J Bus Ventur Entrep. 2016;11(6):39-49. doi:10.16972/apjbve.11.6.201612.39

43. Fayolle A, Gailly B, Lassas-Clerc N. Assessing the impact of entrepreneurship education programmes: a new methodology. J Eur Ind Train. 2006;30(9):701-720. doi:10.1108/03090590610715022
Journal of Multidisciplinary Healthcare

\section{Publish your work in this journal}

The Journal of Multidisciplinary Healthcare is an international, peerreviewed open-access journal that aims to represent and publish research in healthcare areas delivered by practitioners of different disciplines. This includes studies and reviews conducted by multidisciplinary teams as well as research which evaluates the results or conduct of such teams or healthcare processes in general. The journal

\section{Dovepress}

covers a very wide range of areas and welcomes submissions from practitioners at all levels, from all over the world. The manuscript management system is completely online and includes a very quick and fair peer-review system. Visit http://www.dovepress.com/testimonials. php to read real quotes from published authors. 